\title{
A STRUCTURAL APPROACH TO THE ANALYSIS OF SPANISH INTONATION
}

\author{
ANn ANThony \\ University of Michigan
}

$V^{3}$

ERY LITTLE has been done with a phonemic or structural analysis of Spanish intonation." A knowledge of the significant levels of pitch and intonation contours of Spanish could be an important tool in teaching Spanish or in teaching English to students with a Spanish language background. The goal of this brief paper is to indicate the lines along which a structural analysis might proceed. It represents only a small part of a larger investigation which I hope to complete in the future. I am grateful to my informant, Miss Ana Castillo, from Barquisimeto, Venezuela, for her cooperation in furnishing the oral material for this study. ${ }^{2}$ Many of the conclusions must necessarily be tentative until investigation has been made of all types of utterances in the language. The factor of dialect differences must also be kept in mind. A superficial check of the intonation of several speakers from Caracas showed similar patterns, somewhat differently distributed. It is hoped, however, that the material to be presented will bring to light some characteristics of Spanish intonation typical of the language as a whole.

Intonation may be said to be the melody or the music given to spoken language. Professor Kenneth L. Pike remarks, "The changes of pitch which occur within a sentence are not haphazard variation. In each language .... the use of pitch fluctuation tends to become semi-standardized, or formalized, so that all speakers of the language use basic pitch sequences in similar ways under similar circumstances. These abstracted pitch sentence melodies may be called intonation contours." 3

1 There is some excellent material by Navarro Tomás in his Manual de Entonación Española (Hispanic Institute in the United States, New York, 1944.) but it is written from a phonetic, rather than a phonemic or structural standpoint.

2 Miss Castillo at the present time is a student of English at the English Language Institute of the University of Michigan.

${ }^{3}$ Kenneth L. Pike, Intonation of American English, University of Michigan Press, Ann Arbor, 1947, page 20. 
Intonation lends shades of meaning over and above the lexical meaning of an utterance. The temporary meaning given by intonation is determined by the speaker's attitude.

As spoken by this informant, Spanish has four distinctive levels of pitch. This conclusion was arrived at after considerable study of Sound-Scriber and phonetic symbol transcriptions of the oral material given by the informant. Examples from this material will be cited throughout the paper. The four pitch levels will be represented by numbers from 1, indicating the highest level, to 4, indicating the lowest. An abrupt fall or rise in pitch between syllables will be indicated by a number under the syllable first affected by the change in pitch. All succeeding syllables which are unmarked have the same pitch level as the preceding marked syllable:

$$
\underset{3}{P e r o} \text { iqué 'día tan maravilloso! }
$$

A glide up or down within a syllable will be shown by two adjacent numbers beneath the syllable, indicating the pitch at the start and the end of the glide:

$$
\begin{array}{r}
\text { no } \\
24
\end{array}
$$

Sentence stress will be indicated by ' before the syllable receiving the stress. An approximate English translation will be given for each example. All of the examples to be used were heard or elicited and carefully checked by building up situations in which the desired attitude or emotion would be present. In no case was a form used which was spoken only in isolation or out of context.

Four levels are necessary for a complete description of the differences of meaning of the intonation in the material studied. It is significant that four levels are necessary in the description of English intonation also. In our study of Spanish we began by postulating five distinct levels, but further study showed four to be enough. Fewer than four levels would leave unexplained some intonation changes with their accompanying changes of meaning. More than four levels resulted in an unnecessarily over-complicated description with some levels not involving distinctions of meaning. The four levels of pitch are not absolute levels. Instead, they are relative, with the distances between levels fluctuating. The informant's speech 
shows the intervals between the four levels to be somewhat different. Levels 2 and 3 seem to be closer in pitch than any other two successive levels. In abstraction, the four levels might be represented thus:

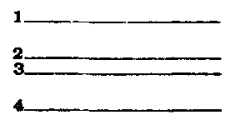

It would be necessary to examine the intonation of many other speakers of Spanish, in different geographic locations and from different social groups, in order to determine whether this distribution of levels is universal or merely a personal or regional characteristic.

We began by transcribing the intonation of numerous questions of varying types, some with interrogatives, others without, some with inverted word order, others with the normal word order of statements. From this material we found that a great number of examples had a similar up-curve from 4 to 1 beginning on the syllable receiving the last sentence stress. The earlier parts of the questions, that is, before the last sentence stress, varied somewhat, but the final 4-1 rise remained constant. This general type of contour, then, in the informant's speech, is the normal, matter-of-fact question pattern, regardless of the grammatical structure involved, Almost all deviations from this intonation pattern, as will be shown, involve some specialized meaning or indicate a particular emotional attitude of the speaker which would not be present in a matter-of-fact question. A number of examples of this normal question pattern follow:

With interrogative:

¿Por 'qué me lla'maste?

(Why did you call me?)

EDonde 'vives?

(Where do you live?)

¿Donde has es'tado?

(Where have you been?)

¿Dónde está el 'libro?

(Where is the book?)

¿Qué estds ha'ciendo?

(What are you doing?)

4 Compare the final 3-2 and 4-2 contours of the questions in English. See Charles C. Fries, An Intensive Course in English for Latin-American Students, Volume I, University of Michigan Press, Ann Arbor, Michigan, 1944, p. 106. 
¿Qué estás estu'diando?

(What are you studying?)

Without interrogative:

$\underset{z}{T} u$ vas a 'casa?

(Are you going home?)

¿Estás can'sada?

(Are you tired?)

¿Llegó el co'rreo?

(Did the mail come?)

¿Es el 'quince?

(Is it the fifteenth?)

${ }_{3}^{R} \operatorname{Reci}_{2}$ biste una 'carta?

(Did you receive a letter?)

Ya hiciste las lec'ciones?

(Did you do the lessons yet?)

¿Lle'gó tu ma'má?

(Did your mother arrive?)

$\underset{3}{T}{ }_{2}^{\prime} \underset{3}{\text { gusta }}$ el ca'fé?

(Do you like the coffee?)

$\underset{3}{i} \mathrm{Na}_{\mathbf{2}}^{\prime} \mathrm{ció}_{3} \underset{3}{\mathrm{U}} \mathrm{d}$. en $\mathrm{De} e^{\prime}$ troit?

(Were you born in Detroit?)

A very few exceptions to this pattern were found for questions of this type. These exceptions were:

¿Donde 'vives?

¿Dónde has es'tado?

Cómo se dice esta pa'labra?

¿Qué es 'esto?

í Cómo le 'gusta?
(Where do you live?)

(Where have you been?)

(How do you say this word?)

(What is this?)

(How do you like it?)

The first two examples in the list immediately above were arrived at by asking the informant, "How does this sound to you?" They are, it will be noticed, identical to questions given in the list with the 
normal up-curve, with only the intonation changed. The informant said that ${ }_{i}$ Donde 'vives? with the $2-4$ falling contour sounded like a spoiled child, accustomed always to having what she wanted. iDbnde has es'tado? with the 2-4 falling contour sounded like "a woman who henpecks her husband." Both of these reactions suggested an aggressive attitude, expressed by the intonation pattern alone.

When we were recording some of this material on Sound-Scriber discs, the informant pronounced the third question

$$
\text { Cómo se dice esta pa'labra? }
$$

Later, after listening to the recording, she wished to change it to

$$
{ }_{3} \text { Como se dice esta pa'labra? }
$$

She remarked that if one were to use the first form (with the 2-4 falling contour), it would sound impolite or abrupt.

The last two exceptions are not so easily explained. ¿QQué es 'esto? with the 2-4 falling contour seemed to be interchangeable with the same question with the 4-1 rising contour without a difference in meaning or attitude. - 'Como le 'gusta? with the 2-4 falling contour occurred as the normal intonation for that question. This final 2-4 fall beginning with the last sentence stress might be used for short, formalized questions, which, through frequent use, acquire a fairly fixed intonation. However, this problem must be investigated further before any definite conclusion can be reached. It is important to notice that in some cases the 2-4 final contour substituted for the normal 4-1 rise adds a connotation of aggressiveness, abruptness, or impoliteness to the question.

It was pointed out earlier that questions with a 4-1 final rise are normal, matter-of-fact questions. Some of these same questions, however, appear with a final 2-4 falling contour when the speaker expects the listener to agree with him. The speaker expects a particular affirmative or negative response. (Negative questions expect negative responses; affirmative questions expect affirmative responses.) This type of question, both negative and affirmative, may be followed by ${ }_{i}$ no? or $i v e r d a d ?^{5}$ For example, we saw that ${ }_{i} T \dot{u}$

${ }^{5}$ Questions of this type in Spanish can be compared with attached questions

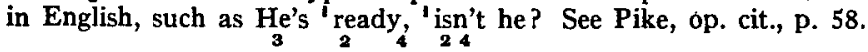


vas a 'casa? with 4-1 rising contour was the normal question. The use of a 2-4 fall instead of the final rise indicates that the speaker is expecting an affirmative answer. $i T \dot{u}$ vas $a$ 'casa? with a 2-4 fall expects $S i$, voy a casa (Yes, I am going home.), although that answer may or may not be forthcoming. Other examples of the same type follow:

¿Tu es'poso está a $a_{2}^{\prime} q u i ?$ (Is your husband here?)

expects Si. Está aqui. (Yes. He is here.)

$i_{2}^{\prime} T u$ no vives a'qui? (You don't live here, do you?)

expects No. No vivo aqui. (No. I don't live here.)

$\underset{3}{i} \mathrm{Na}_{3}^{\prime}$ ciste en De'troit? (Were you born in Detroit?)

expects Si. En Detroit. (Yes. In Detroit.)

${ }_{3}$ No tienes ningún 'niño? (You don't have any children, do you?)

expects No. No tengo. (No. I don't have any.)

An element of surprise seems to be added to the foregoing questions by changing the final 2-4 contour to 1-4. That is:

¿Tú vas a'casa?

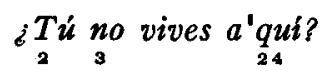

$i_{3} T u$ es' $\underset{3}{p a s o}$ está $a^{\prime} q u_{24}^{\prime}$ becomes

becomes

becomes
¿Tú vas a 'casa?

¿Tú no vives a' $\underset{3}{\text { quí? }}$

$\sum_{3}^{T}$ es ${ }_{2}^{\prime}$ poso está a' quí?

In these examples level 1 can vary considerably, depending on the degree of surprise. All variations denoting surprise are higher than level 2. Since no basic change in meaning is shown, but rather various grades of the same meaning, these levels denoting surprise are variants of level 1. No extra distinctive level or levels are necessary to describe them. ${ }^{\circ}$

B It should also be stated here that level 1 of a falling curve seems to be phonetically somewhat higher than the level 1 of a 4-1 rise in the normal question pattern. However, both are higher than level 2, and they never occur in distinctive contrast. They are therefore variants of the same phonemic level, conditioned by the type of intonation contours of which they are a part. 
Another type of question is one in which emphasis is placed upon a particular word in order to contrast it with another part of the utterance. This emphasis is achieved by a 1-4 contour, as was surprise in the questions in the preceding list. A question of this type differs in intonation from the normal question as shown by the following examples:

Normal: ¿'Qué estás estu'diando? (What are you studying?)

Emphatic Contrast:

'Sé que estás en Ann 'Arbor, pero ¿qqué estás estu'diando?

(I know that you are in Ann Arbor, but what are you studying?)

Normal: $\dot{\sigma}^{\prime}$ Cuál es tu direc'cion? (What is your address?)

Emphatic Contrast:

'Yo 'se donde 'vives, pero ¿'cuál es tu direc' ción?

(I know where you live, but what is your address?)

Normal: 'G'Cuándo llegaste a Ann 'Arbor? (When did you arrive in Ann Arbor?)

Emphatic Contrast:

'Yo 'sé cuando llegaste a los Estados U'nidos, pero

23

S'cuándo llegaste a Ann 'Arbor?

(I know when you arrived in the United States, but when did you arrive in Ann Arbor?)

It should not be assumed that the intonation patterns which have been discussed here occur exclusively with questions. The same falling and rising contours occur with other types of utterances. Level 1 is used throughout the language to connote surprise or strong emphasis. The attitude of the speaker, not the grammatical structure of the utterance, determines the intonation.

This study represents only the beginning of a structural or phonemic analysis of Spanish intonation. Many problems are left unsolved; many questions remain unanswered. Numerous contours 
have not been described. Factors such as length, stress, and rhythm, all of which affect intonation, remain to be investigated. For teachers of Spanish or for those who teach other languages to native Spanish speakers, a complete analysis of all these factors would contribute greatly toward effective language teaching. 